\title{
STUDIES OF DIETARY PHYTOESTROGEN FROM MOMORDICA CHARANTIA LINN. SEEDS
}

\section{Estudios de fitoestrógeno en la dieta a partir de semillas de momordica charantia Linn.}

\author{
Sharanabasappa A. Patil \\ Reproductive Endocrinology Laboratory, Department of Zoology, Gulbarga University, India.
}

Corresponding to: Dr. Sharanabasappa A. Patil. E-mail: sshanu@rediffmail.com

Receipt: $31 / 07 / 2020$

Acceptance: $18 / 08 / 2020$

\begin{abstract}
Phytoestrogens are secondary plant metabolites produced by plants that are similar in structure of estrogen. Human consumption of these compounds has been associated with many health benefits. In this study, we investigated the potential phytoestrogen content of dietary Momordica charantia Linn. (Bitter melon) seeds were collected from the Hyderabad-Karnataka regions of India. A phenolic dietary phytoestrogen has been isolated from the crude ethanol extract of Bitter melon seeds. After preparative HPLG whitish amorphous compound was yielded. The HPLG purified compound is subjected to spectral analysis using IR, NMR and MS. The spectral data revealed that the phenolphthalein a phytoestrogenic molecule is present in the ethanol extract of dietary Bitter melon seeds.
\end{abstract}

Key words: Momordica charantia, Bitter melon, Dietary phytoestrogen

\section{Introduction}

Phytoestrogens are plant derived compounds that structurally or functionally mimic mammalian estrogens and therefore are considered to play an important role in the prevention of cancers, heart disease, menopausal symptoms and osteoporosis (Adlercreutz, 1995). People are seeking complementary and alternative practices of health care as well as treatments seen as more 'natural' as a way to competent biomedical health care. The compounds are weaker than natural estrogens and reside in herbs and seasonings (garlic, parsley), grains (soybeans, wheat and rice), vegetables (beans, carrots, potatoes and bitter melon), fruits (date, pomegranates, berries and apples) and drink (coffee). Most of us are exposed to many of these natural compounds through food (fruits, vegetables and meat). The three most studied groups of phytoestrogens are the lignans (grains, fibers, flax seeds, 
fruits and vegetables), isoflavones (found in soybeans and legumes) and the phenolics (found in bitter melon) (Liu, 2001: Kronenberg, 2002). All in all, there are differing opinions about phytoestrogens role in health. When consumed as part of an ordinary diet, phytoestrogens are probably safe and may even be beneficial.

Estrogen is a compound that plays a vital role in the female body of humans and other animals. Estrogen has many functions in the body including the development of breasts, the thickening of endometrium, and regulating the menstrual cycle (Nelson, 2009). Menopause occurs when a woman naturally stops producing eggs and the body produces less estrogen (Zieve, 2011). Menstruation becomes less frequent and eventually stops. However, it is important for females to continue to receive estrogen even after menopause in order to continue their daily lives comfortably and to avoid medical complications. Instead of taking estrogen, which can increase the risk of breast cancer, phytoestrogens can provide a safer alternative to receive estrogen (Warren, 2011). Phytoestrogens can increase proliferation in estrogen receptor expressing cells and can modulate estrogen receptor signaling.

In the present status the regulation and awareness are required on standardization, preparation and extraction methods of phytoestrogen products being sold and marketed as nutritional supplements. As nutritional and herbal supplements these products are not supported by preclinical/clinical trials and therefore should be administered and must be taken into consideration. One of the best examples of these herbs is Bitter melon. Different parts of Bitter melon as an Ayurvedic medicine/dietary product it has promising well documented uses in all parts of world. Bitter melon reduces the amount of glucose that is released into the blood by inhibiting the enzymes that break down disaccharides to two monosaccharides like glucose (Oishi, 2007; Kumar Shetty, 2005). Bitter melon can influence the transport channels for glucose, which also reduces glucose transport into the blood. This effect is important for the treatment of both Type I and Type II diabetic patients and helps to prevent high blood sugar levels after meals. In mice and rats, bitter gourd has been shown to reduce hypertension (Singh, 2004), plasma cholesterol and plasma lipids (Nerurkar, 2008). Bitter melon is used for various stomach and intestinal disorders including gastrointestinal (GI) upset, ulcers, colitis, constipation, and intestinal worms. It is also used for kidney stones, fever, a skin condition called psoriasis, and liver disease, as supportive treatment for people with HIV/AIDS and to start menstruation. Our previous studies showed the extracts of Bitter melon seeds have some of active estrogenic activity (Sharanabasappa, 2002) and represent a novel class of phytoestrogens and positive phenolic test on preliminary phytochemical analysis (Patil, 2011). Therefore, phytoestrogens from Bitter melon may have beneficial effects for peri and postmenopausal women.

In this project, we are studying phytoestrogen in the plant Bitter melon. Bitter melon is grown in tropical areas, including Asia, the Amazon, East Africa, and Caribbean and throughout South America where it is used as food, as well as a medicine. Bitter melon is an annual fast growing, slender, climbing vine, thin stems and tendrils producing flowers in the leaf axils. The fruits are edible and used for culinary purposes and decoctions of the fruits and leaves in medicine. The bitter melon fruits are oblong in shape and warty - looking, resembling pickling cucumbers. The young fruits are green and turn to orange - yellow when ripe. This plant produces a fruit seeds and is used as a food source a well as indigenous system of medicine. Previous research gave us the idea that phytoestrogens exist in Bitter melon (Sharanabasappa, 2002). Bitter melon has been recommended to alleviate gynecological disorders with reference to the frequently observed menstrual disorders in female an estrogenic mode of action. The objective of our research is to continue to test Bitter melon extracts to look for phytoestrogenic activity and to isolate different compound/s in the plant in order to find the compound that may act as a phytoestrogen. 


\section{Materials and methods}

Chemicals: The materials like Silica gel - G for thin layer chromatography (Qualigens fine chemicals Mumbai), Silica gel (60-120 mesh) for column chromatography (Sisco research laboratory Pvt. Ltd. Mumbai), ceric sulphate and solvents petroleum ether, benzene, chloroform, ethyl acetate, methanol, butanol, ethanol (S. D. fine chemicals Baroda) were used.

Plant material: The ripe Bitter melon fruits were collected from the agricultural fields of Hyderabad - Karnataka region, India in the month of December and authenticated in Department of Botany Gulbarga University, Gulbarga. The voucher specimen (HGUG-905) has been deposited in the herbarium. The mature seeds were removed from the fruits and shade dried at room temperature.

Extract preparation: The Bitter melon seeds were powdered and subjected to soxhlet extraction (hot extraction) with various solvents with increasing polarities (petroleum ether, benzene and ethanol). All the extracts were concentrated to dryness in flash evaporator (Buchi) with reduced pressure and controlled temperature $\left(40-50^{\circ} \mathrm{C}\right)$.

Semi purification of extract: To semi fractionation from ethanol extract, water was added to it and extracted repeatedly with n-butanol. The n-butanol layer was separated and concentrated to dryness in flash evaporator. The compounds having high $\mathrm{Rf}$ value $(\mathrm{Rf}=0.60)$ was designated as Fraction I, and compounds having low $\mathrm{Rf}$ value $(\mathrm{Rf}=0.35)$ were designated as Fraction II. The Fraction I was further purified by subjecting to column chromatography over silica gel (60-120 mesh) successively eluting with petroleum ether, petroleum ether-chloroform, chloroform, chloroform-ethyl acetate, ethyl acetate, ethyl acetate-methanol and finally methanol in increasing order of polarity. The column elution yielded four sub fractions $\left(\mathrm{S}_{1}-\mathrm{S}_{4}\right)$.

HPLC analysis: The experiment was carried out using as Agilent 1100 HPLG series system. HPLC analysis of four fractions $\left(\mathrm{S}_{1}-\mathrm{S}_{4}\right)$ was conducted on Spherisorb ODS 1 column $(25 \times 4.6 \mathrm{~mm}$ i.d) at ambient temperature, using mobile phase (methanol-water $50: 50 \mathrm{v} / \mathrm{v}$ ) at a flow rate of $2 \mathrm{~mL} / \mathrm{min}$ with injection of $20 \mu \mathrm{L}$. UV detection was at $215 \mathrm{~nm}$.

Spectroscopic analysis: The compound after fractionation by HPLC is yielded a white amorphous powder $(98.89 \%$ purity) further subjected to spectral studies. The IR spectrum was obtained on 460 Shimadzu spectrometers. ${ }^{1} \mathrm{H}$ NMR spectra were recorded on JEOL JNM - A 500 NMR spectrometer and solvent methanol was used for spectral analysis. Mass spectra were recorded on JMS HX - 110 with a data system and on JMS - DA 500 mass spectrometers.

Phytoestrogenic nature of phenolphthalein: Bioassay-guided fractionation led to the isolation of amorphous phenolphthalein compound. Hence, it was subjected to in vivo estrogenic activity (Animal ethics Reg. No. 34800/2001/CPAEA). Colony bred immature female albino rats of 25-30 days old, weighing between $30-40 \mathrm{~g}$ were bilaterally ovariectomised to observe the phytoestrogenic nature of phenolphthalein. The treatments were given from 7 days. On day $8^{\text {th }}$ the rat uteri were dissected out and weighed for gravimetric analysis. Vaginal smears changes were recorded daily from these experimental immature rats.

The Figure 1 show a schematic diagram showing the preparation and isolation of phytoestrogen (Phenolphthalein) from Momordica charantia Seeds 
Figure 1

Schematic diagram showing the preparation and isolation of phytoestrogen (Phenolphthalein) from Momordica charantia Seeds

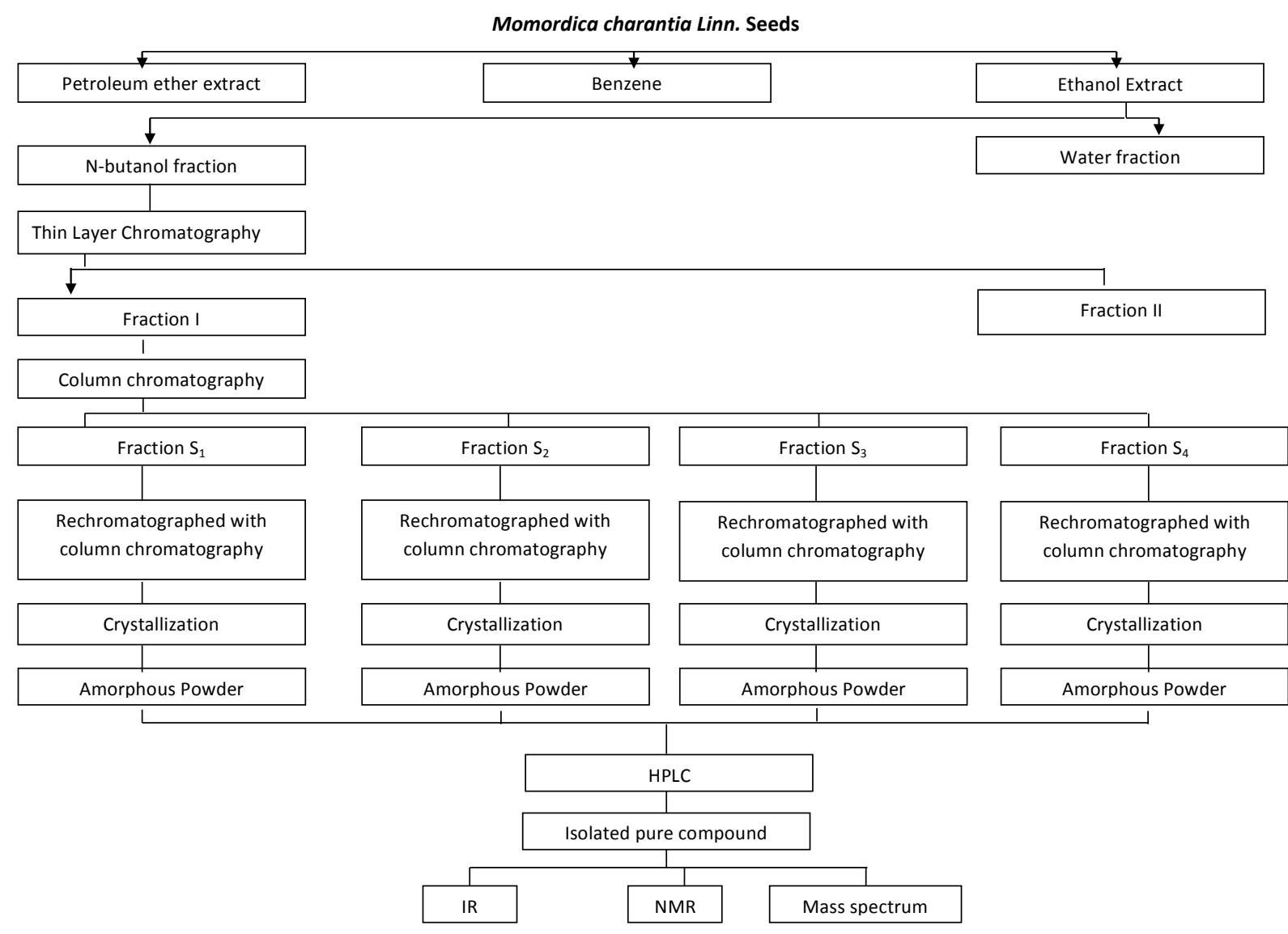

\section{Results and discussion}

The Bitter melon seeds extract container when taken for a wash pink colour appears, as the laboratory tap water has got $\mathrm{pH}$ more than 7 i.e. alkaline $\mathrm{pH}$. This gave an indication that extract may be containing an organic molecule which can give colour in alkaline $\mathrm{pH}$. The variation in the colour caused due to change in $\mathrm{pH}$ is the property of the indicators. When this is repeated with the double distilled water the colour did not appear. This became a strong point to assume that the extract contains suitable indicator which gives no colour at $\mathrm{pH} 7$, but pink colour when $\mathrm{pH}$ is more than 7 . The crude ethanol extract of Bitter melon seeds after preparative TLC over silica gel ' $G$ ', repeated column chromatography and preparative HPLC afforded amorphous in nature compound. Compound isolated as a white amorphous powder, m.p. $261-263^{\circ} \mathrm{c}$, with a molecular formula $\mathrm{C}_{20} \mathrm{H}_{14} \mathrm{O}_{4}$. The IR spectrum (Fig. 2) of amorphous powder exhibited $\delta \mathrm{C}=\mathrm{O}$ peak at $1735 \mathrm{~cm}-1$. This may be due to either $\mathrm{C}=\mathrm{O}$ of carboxylic ester or $\mathrm{C}=\mathrm{O}$ of lactone. The two sharp peaks were observed at 3378 cm-1 and $3290 \mathrm{~cm}-1$ corresponding phenolic hydroxyl, groups. In the NMR spectrum (Fig. 3) of this compound the aromatic cluster is seen from $6.352-7.8 \delta$ corresponding to the resonance of aromatic protons. A sharp singlet is seen at $9.7 \delta$ which can be accounted for proton of phenolic - OH. In the mass spectrum (Fig. 4) of compound the molecular ion peak $\mathrm{M}+$ is appeared at 318 corresponding 
Figure 2

IR spectrum of isolated compound

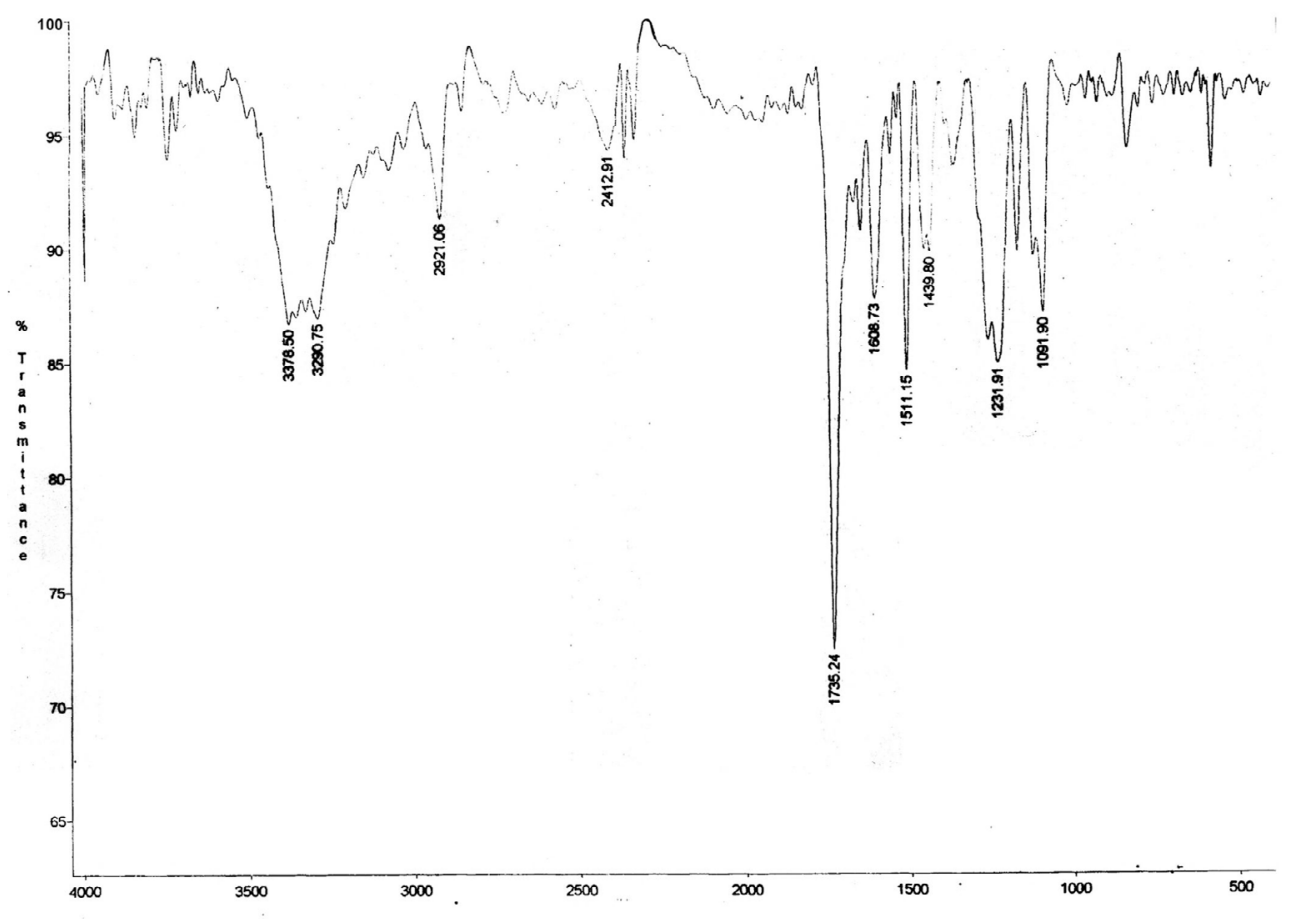

Figure 3

IH NMR spectrum of isolated compound

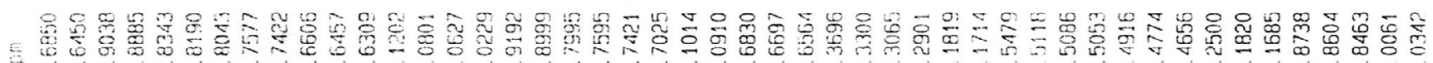
E क
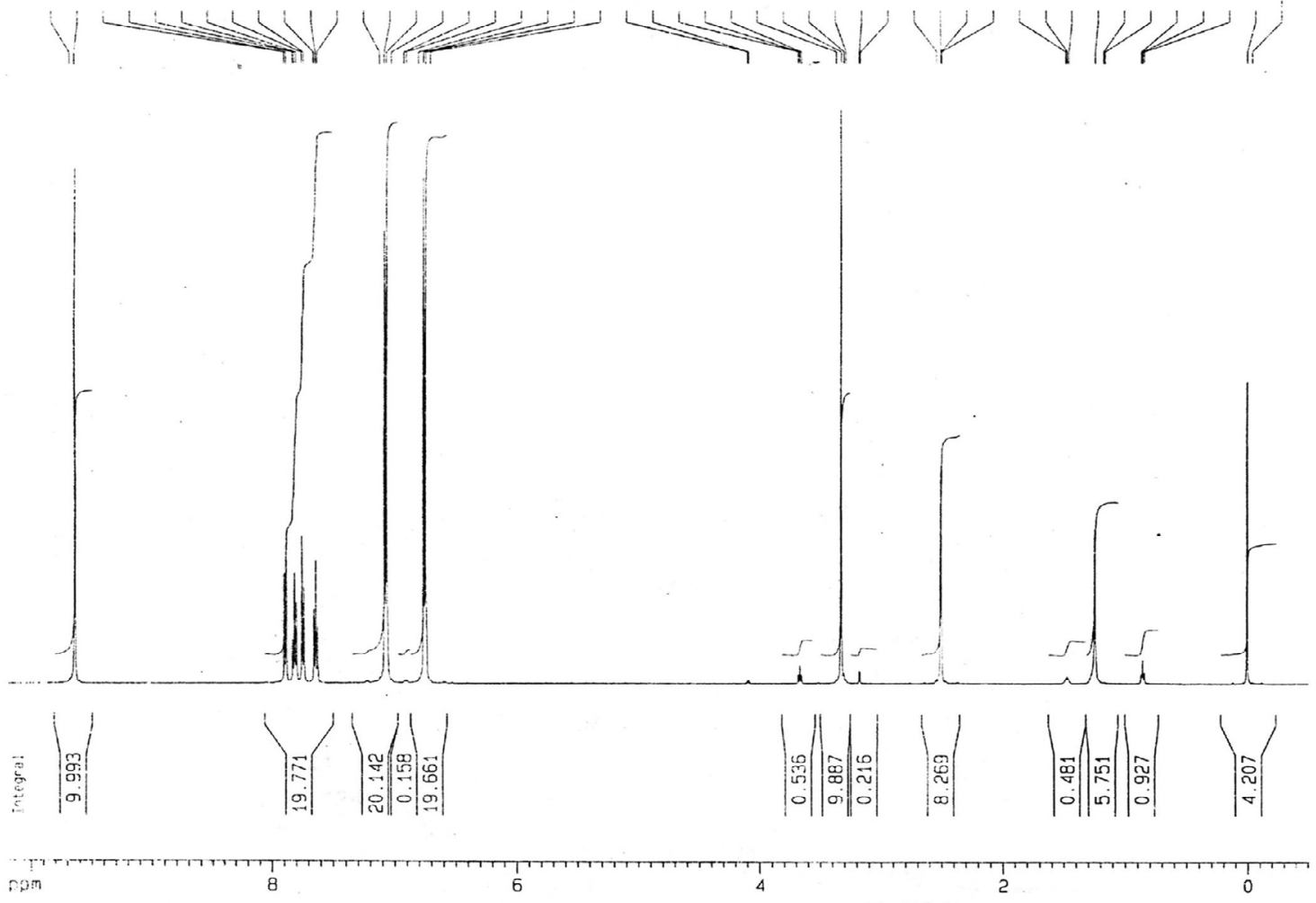
Figure 4

Mass spectrum of isolated compound

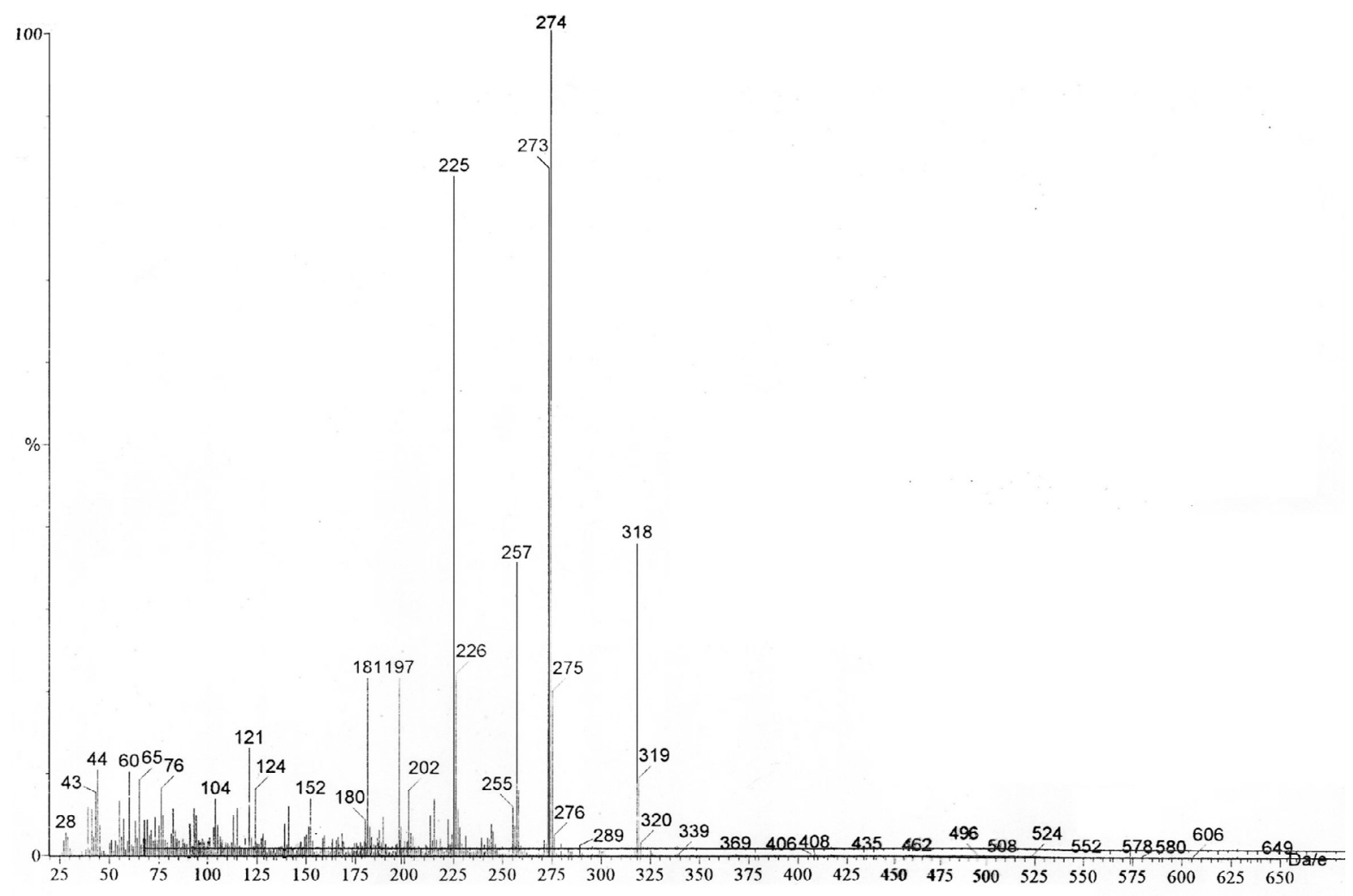

to the molecular weight of the phenolphthalein molecule. This molecular ion peak has lost $\mathrm{CO}_{2}$ to give a base peak at $\mathrm{m} / \mathrm{z} 274$. These spectral data suggest that the compound isolated from the ethanol extract of seeds of Bitter melon contains a phenolphthalein molecule.

It was found that the compound isolated was phenolphthalein, which possess triphenyl ring. The existing compounds like tamoxifen and enclomiphene, which are used in contraceptives, also possess triphenyl ring system. Therefore, the phenyl ring is the principal structural feature responsible for selective affinity binding to estrogen receptors. From the comparison of the structures of tamoxifen, enclomiphene and phenolphthalein, it reveals that the substituted phenyl ring systems need not be present on the vinyl systems, compared to the synthesis of tamoxifen and enclomiphene. Another interesting point to be noted here is, the phenolphthalein behaves as an estrogenic and antiestrogenic at varying dose levels, indicating both the actions are associated with single molecule.

Significant increase in its weight in phytoestrogen treated animals is observed when compared to control. The vagina of rats opened by $3^{\text {rd }}$ day of isolated phytoestrogen treatment, while the vagina of all the control rats remained closed; this observation indicates strong estrogenic nature of phytoestrogen isolated from dietary plant. The dose dependent cornification in the vaginal cells is also noticed due to the administration of phytoestrogen.

It is surprising to note that such molecule is present in a most common vegetable Bitter melon. We have not made an attempt to establish its biogenesis in the Bitter melon plant. There are reasonable numbers of reports in the literature during the last 10-15 years regarding the carcinogenic properties of phenolphthalein molecule. These reports are based on the experiments carried out on Rodents. 
But researchers have not yet established the carcinogenicity of phenolphthalein in human beings. The phenolphthalein is present as a major constituent of many drugs, available across the bench without the specific prescription of physicians. There are good numbers of users who are not following the regulated doses of drugs containing phenolphthalein. This molecule is present in laxatives and is in use. Hence the Bitter melon extract, even though it contains phenolphthalein molecule, it is not carcinogenic. Phenolphthalein, a whitish odorless, tasteless powder is reported to be a multispecies carcinogen at dietary doses of $450-2900 \mathrm{mg} / \mathrm{kg}$ body weight. But in our studies the Bitter melon seeds exhibited its contraceptive (antiimplantational) activity (Sharanabasappa, 2010); highly enhanced estrogenesis (Sharanabasappa, 2002) and reduction in the sperm count (Patil, 2011) at the dose of $200 \mathrm{mg} / \mathrm{kg}$ body weight. This dosage is for less than the concentration required to induce the carcinogenicity in rats. This encourages extending this work on higher animals to establish that the extract of Bitter melon seeds will be safest ayurvedic preparation for the regulation of fertility. It appears that it can be prepared as a home remedy within the reach of common man.

\section{Conclusions}

The seed extract of this dietary (vegetable) plant indicates the presence of phenolic phytoestrogens. On phytochemical screening the ethanol extract showed positive test for phenolics. Most phytoestrgens belong to isoflavonoids, coumestans, lignans and phenolic groups. Interestingly, in recent years, the popularity of different kinds of pharmaceutical preparations containing phytoestrogens has constantly increasing. This prompted us to proceed to study the seed phytoestrogen. This leads to discovery of newer phytoconstituents with better activities and provide source of new biomolecules for biologists to work on. The studies explore the utilization of medicinal/dietary plants for effective management. It gives a larger platform for the medicinal plant growers by providing scientific support and data to the traditional invalidated herbal drugs. Taking account of all these facts, the present study was undertaken.

\section{Acknowledgement}

Financial support (Grant Number: SERB sanction letter No. F. No. SR/FT/LS-129/2009) from Science and Engineering Research Board, New Delhi, India for awarding Principal investigator, fast track young scientist scheme to Dr. Sharanabasappa A. Patil is gratefully acknowledged.

\section{Conflict of interest disclosure}

There is no conflict of interest.

\section{References}

Adlercreutz H, Phytoestrogens: epidemiology and a possible role in cancer protection. In: McLachlan JA, Korach KS, eds. Estrogens in the environment, III: global health implications, Environmental Health Perspectives, 1995, 103(Suppl 7), 103-112.

Kronenberg F, Fugh-Berman A, Complementary and alternative medicine for menopausal symptoms: a review of randomized, controlled trails, Annals of Internal Medicine, 2002, 137, 805-813.

Kumar Shetty A, Suresh Kumar G, Veerayya Salimath P, Bitter gourd (Momordica charantia) modulates activities of intestinal and renal disaccharidases in streptozotocin-induced diabetic rats, Molecular Nutrition and Food Research, 2005,49(8), 791-796. 
Liu J, Burdette JE, Xu H et al., Evaluation of oestrogenic activity of plant extracts for the potential treatment on menopausal symptoms, Journal of Agricultural Food Chemistry, 2001b, 49, 24722479 .

Nelson L, Menstruation and the menstrual cycle fact sheet, Women's Health, National Institutes of Health, 21 Oct 2009. Web. 8 Nov 2011.

Nerurkar PV, Lee YK, Motosue M, Adeli K, Nerurkar VR, Momordica charantia (bitter melon) reduces plasma apolipoprotein B-100 and inrcreases hepatic insulin receptor 11 substrate and phosphoinositide-3 kinase interactions, British Journal of Nutrition, 2008, 100(4), 751-759.

Oishi Y, Sakamoto T, Udagawa H, Taniguchi H, Kobayashi-Hattori K, Ozawa Y, Takita T, Inhibition of increases in blood glucose and serum neutral fat by Momordica charantia saponin fraction, Bioscience, Biotechnology and Biochemstry, 2007, 71(3), 735-740.

Patil SA, Patil SB, Toxicological studies of Momordica charantia Linn. Seed extracts in male mice, International Journal of Morphology, 2011, 29(4), 1212-1218.

Sharanabasappa AP, Vijaykumar B, Saraswati BP, Effect of Momordica charantia seed extracts on ovarian and uterine activities in albino rats, Pharmaceutical Biology, 2002, 40, 501-507.

Sharanabasappa AP, Saraswati BP, Contraceptive potential of phenolphthalein isolated from the seeds of Momordica charantia (Cucurbitaceae), Asian Journal of Pharmacodynamics and Pharmacokinetics, 2010, 10(1), 53-58.

Singh J, Adeghate E, Cummings E, Giannikipolous C, Sharma AK, Ahmed I, Beneficial effects and mechanism of action of Momordica charantia juice in the treatment of streptozotocin-induced diabetes mellitus in rat, Molecular and Cellular Biochemistry, 2004, 261(1-2), 63-70.

Warren, Barbour, Carol D, Phytoestrogens and Breast Cancer, Breast Cancer and Environmental Risk Factors, Cornell University, 07 2001. Web. 8 Nov 2011.

Zieve D, Susan S, Menopause, Pub Med Health, National Institutes of Health, 1109 2010. Web. 8 Nov 2011.

\section{RESUMEN}

Los fitoestrógenos son metabolitos vegetales secundarios, producidos por plantas que tienen una estructura similar al estrógeno. El consumo humano de estos compuestos se ha asociado con muchos beneficios para la salud. En este estudio, investigamos el contenido potencial de fitoestrógenos de Momordica charantia Linn en la dieta. Se recolectaron semillas (melón amargo) de las regiones de Hyderabad-Karnataka de la India. Se ha aislado un fitoestrógeno dietético fenólico del extracto de etanol crudo de semillas de melón amargo. Después de HPLC preparativa, se obtuvo un compuesto amorfo blanquecino. El compuesto purificado por HPLC se somete a análisis espectral usando IR, NMR y MS. Los datos espectrales revelaron que la fenolftaleína, una molécula fitoestrogénica, está presente en el extracto etanólico de las semillas de melón amargo en la dieta.

Palabras clave: Momordica charantia, Melón amargo, Fitoestrógeno dietético. 